\title{
PENGGUNAAN AHP UNTUK PEMILIHAN METODE PERENCANAAN ANTARA KONVENSIONAL DENGAN BIM PADA REDESIGN PROYEK KONSTRUKSI
}

\author{
Iwan Supriyadi ${ }^{1}$, Aland Hasbi ${ }^{2}$ \\ ${ }^{1}$ Dosen, Jurusan Teknik Sipil, Politeknik Negeri Jakarta, Kampus UI Depok 16424 \\ ${ }^{2}$ Mahasiswa D-4 TPJJ/JT, Jurusan Teknik Sipil, Politeknik Negeri Jakarta, Kampus UI Depok 16424 \\ Iwansup@yahoo.com, hasbialand@gmail.com
}

\begin{abstract}
During the construction projects, delays usually happen which are mainly caused by reworks, where $60 \%$ of reworks are caused by design failure. Since designs have a major impact on construction projects, there are methods to correctly create a design. Three methods of planning that can be done are conventional, semi-conventional, and BIM methods. The three methods have both advantages and disadvantages. Decision making for method selection for redesigning is very crucial to avoid delays to a project. The three main criteria in method selection are cost, time, and system. This research was done to decide the main criteria, sub-criteria, and an alternative in decision making of method selection for redesigning through the use of AHP (Analytical Hierarchy Process) and analyze conditions on the field with the result of $A H P$ analysis. The result showed that cost was the main criterion with a weight if 0.40 and the sub-criterion for the cost was the HR training cost with a global weight of 0.21. Alternative planning method selected was the BIM method with a global weight of 0.66. The result of field analysis showed that BIM planning method was $60.4 \%$ faster than the conventional method with an increase of training cost by 62.5\%. The conclusion of this research was that BIM planning method was more efficient than conventional and semi-conventional planning in the process of re-design.
\end{abstract}

Key words: Re-design, Conventional, BIM, AHP

\begin{abstract}
ABSTRAK
Pada pelaksanaan proyek konstruksi, keterlambatan dengan rework menjadi penyebab utama dimana 60\% penyebab Rework disebabkan oleh kesalahan desain. Besarnya dampak desain pada proyek konstruksi maka berbagai cara dilakukan untuk menyelesaikan proses desain dengan tepat. Tiga metode perencanaan yang dapat dilakukan yaitu Metode Konvensional, Metode Semi Konvensional, dan Metode BIM. Ketiga metode perencanaan tersebut sama-sama memiliki kelebihan dan kekurangan. Pengambilan keputusan saat pemilihan metode perencanaan pada pekerjaan re-design sangat krusial dalam mengurangi keterlambatan proyek. Banyaknya variabel dan kurangnya kriteria obyektif menyulitkan proses pemilihan metode perencanaan re-design. Tiga kriteria utama dalam proses pengambilan keputusan dalam pemilihan metode perencanaan re-design yaitu biaya, waktu, sistem. Penelitian ini dilakukan untuk menentukan kriteria utama, subkriteria dan alternatif dalam penentuan pengambilan keputusan dalam pemilihan metode perencanaan re-design dengan menggunakan metode AHP (Analytical Hirerachy Process) dan menganalisa kondisi di lapangan dengan hasil analisis AHP. Hasil penelitian menunjukkan biaya menjadi kriteria utama dengan bobot sebesar 0.40 dan subkriteria yang terpilih adalah biaya pelatihan SDM dengan bobot global sebesar 0.21. Alternatif metode perencanaan yang dipilih adalah metode perencanaan BIM dengan bobot global sebesar 0.66. Hasil analisis lapangan juga menunjukan bahwa metode perencanaan BIM lebih cepat $60.4 \%$ dari metode perencanaan konvensional dengan peningkatan biaya pelatihan sebesar 62.5\%. Simpulan dari penelitian ini adalah Metode Perencanaan BIM lebih efisien daripada Perencanaan Konvensional maupun semi-konvensional dalam pengerjaan re-design.
\end{abstract}

Kata kunsi : Re-design, Konvensional, BIM, AHP 


\section{PENDAHULUAN}

Pada pelaksanaan proyek konstruksi, keterlambatan proyek dapat menyebabkan berbagai bentuk kerugian bagi penyedia jasa dan pengguna jasa [1]

Penyebab utama keterlambatan proyek konstruksi adalah Rework. Rework merupakan salah satu kontributor utama pada pembengkakan biaya dan keterlambatan proyek [2] serta menurut penelitian [3] banyaknya pemangku kepentingan dalam proyek yang salah karena terlambat dalam pengambilan keputusan yang disebabkan oleh lamanya alur informasi antar pemangku kepentingan saling bertukar informasi.

Dalam penelitian sebelumnya [4] terhadap 26 kontraktor dan 20 konsultan menyebutkan $60 \%$ penyebab utama keterlambatan proyek karena faktor desain, seperti kesalahan, buruknya koordinasi, dan perubahan desain. Salah satu proyek yang terkendala rework adalah Proyek Strategis Negara (PSN) Jalan Tol Cibitung - cilincing Seksi 2. Proyek yang dijadwalkan rampung awal tahun 2019 tertunda akibat perubahan desain dari at-grade menjadi full-slab. Selain berdampak terhadap waktu, proyek ini juga mengalami kenaikan biaya dari $\mathrm{Rp}$ 4,22 Triliun menjadi $\mathrm{Rp}$ 10,80 Triliun (detik.finance.com,2018).

Berbagai metode design digunakan seperti penggunaan software konvensional seperti Autocad, SAP, Ms.Project. Namun, menurut penelitian [5] pemakaian software konvensional dua kali lebih lama dari software yang saling terintegrasi dalam sistem BIM (Building Information Modeling) dengan kecepatan metode BIM 52,25\% lebih cepat. [6] Konsep BIM membayangkan konstruksi virtual sebelum konstruksi fisik yang sebenarnya, untuk mengurangi ketidakpastian, meningkatkan keselamatan, menyelesaikan masalah, dan menganalisis dampak potensial.
Metode perencanaan untuk pekerjaan redesign atau perubahan desain baik itu dengan metode konvensional, semikonvensional maupun metode BIM sama-sama memiliki kelebihan dan kekurangan. Pemilihan antara 3 pilihan metode tersebut tidak terlepas dari pengambilan keputusan yang berdasarkan analisa baik dari segi biaya, waktu maupun sistem yang akan diterapkan sehingga mempengaruhi proyek konstruksi tersebut. Pengambilan keputusan merupakan hal penting untuk keberhasilan sebuah proyek konstruksi, begitu juga dalam pengambilan keputusan dalam pemilihan metode perencanaan re-design yang sangat berpengaruh terhadap waktu pengerjaan konstruksi [7]. Sehingga pengambilan keputusan saat pemilihan metode perencanaan pada pekerjaan re-design antara metode konvensional, semi konvensional dan metode BIM sangat krusial dalam mengurangi keterlambatan proyek. Banyaknya variabel dan kelebihan serta kekurangan masingmasing metode sehingga menyulitkan bagi pelaku konstruksi memilih metode perencanaan yang efisien, maka metode yang digunakan dalam penelitian ini adalah metode AHP (Analytical Hirerachy Process).

Metode analsisi AHP merupakan metode analisis yang digunakan untuk memperoleh sekala rasio dari pasangan yang berlainan maupun perbandingan pasangan yang terus menerus di dalam struktur hirarki bertingkat. Menurut penelitian [8] metode AHP adalah metode yang paling mudah digunakan untuk memahami masalah yang komplek yang diuraikan kedalam elemen-elemen yang berhubungan. Menurut penelitian [9] AHP mengikuti cara alami atau default dari pemikiran manusia untuk menguraikan masalah-masalah besar yang tidak terstruktur menjadi bagianbagian yang lebih kecil dan lebih bisa diatur. Karakteristik ini yang membuat AHP menjadi sangat serbaguna dan 
mudah beradaptasi sehingga memungkinkan kita untuk mengerti lebih dalam dan memecahkan beragam macam masalah dari berbagai bidang disiplin. Secara umum AHP adalah suatu kerangka nonlinear untuk mengeksekusi baik pemikiran deduktif dan induktif tanpa menggunakan silogisme. Hal ini memungkinkan mengambil beberapa faktor dalam pertimbangan dengan bersamaan, memungkinkan pembuatan hubungan ketergantungan dan umpan balik serta pembuatan timbal balik dalam bentuk angka pada tiruan atau kesimpulan [10].

Tujuan dari kegiatan penilitian ini adalah untuk menentukan hasil analisis AHP terhadap perbandingan metode perencanaan re-design di Proyek Jalan Tol Cibitung-Cilincing Seksi II.

\section{METODE PENELITIAN}

Penelitian ini menggunakan metode analisis AHP (Analitical Hierarchy Process) dengan proses pemungutan suara (kuesioner) yang dilakukan di site Proyek Jalan Tol Cibitung-Cilincing Seksi II serta Departemen BIM Divisi VII PT. Waskita Karya (Persero) Tbk. yang melibatkan Kepala Teknik site, Staf Teknik site, BIM Expert, BIM Engineer, dan konsultan perencana dimana pemilihan responden tersebut didasarkan atas pengalaman responden dalam pengambilan keputusan.

Analisis AHP dimulai dengan pendefinisian kriteria dan sub-kriteria yang berpengaruh untuk proses redesign di Proyek Jalan Tol CibitungCilincing Seksi II serta pembuatan hirarki sehingga didapatkak alternatif metode perencanaan re-design berupa Metode Perencanaan Konvensional, Metode Perencanaan Semi-

\footnotetext{
${ }^{1}$ Kepala Teknik site Proyek Jalan Tol CibitungCilincing, Staf Teknik site Proyek Jalan Tol Cibitung-Cilincing, BIM Expert, BIM Engineer
}

Konvensional, dan Metode Perencanaan BIM.

Penelitian ini juga menggunakan data sekunder biaya berupa biaya software, hardware, dan pelatihan SDM serta data waktu berupa waktu pelatihan SDM dan waktu re-design sehingga data sekunder yang telah didapatkan bisa dianalisis dan dibandingkan dengan hasil pemilihan alternatif dari analisis AHP. Perbandingan data AHP dan data sekunder didapatkan prioritas alternatif, prioritas kriteria utama, dan sub-kriteria utama.

Tahapan pekerjaan dan proses analisa dari metode AHP ini dimuali dengan pendefinisian kriteria dan sub-kriteria sebagai perincian pemecahan masalah. Selanjutnya membuat struktur hirarki yang diperoleh dari informasi berdasarkan sudut pandang yang menyeluruh, dari tingkatan puncak hirarki hingga tingkatan dimana campur tangan untuk memecahkan persoalan yang diinginkan dapat dilakukan. Setelah proses pembuatan hirarki dilanjutkan dengan pengumpulan data primer dengan melakukan kuisioner kepada ahli ${ }^{1}$. Penganalisisan data primer berupa hasil kuisioner dilakukan dengan perhitungan geometric mean hingga pengujian konsistensi AHP dan pengujuan konsistensi hirarki untuk menentukan nilai bobot alternatif serta peringkat kriteria dan sub-kriteria.

PT. Waskita Karya Divisi VII, dan Konsultan Perencana 


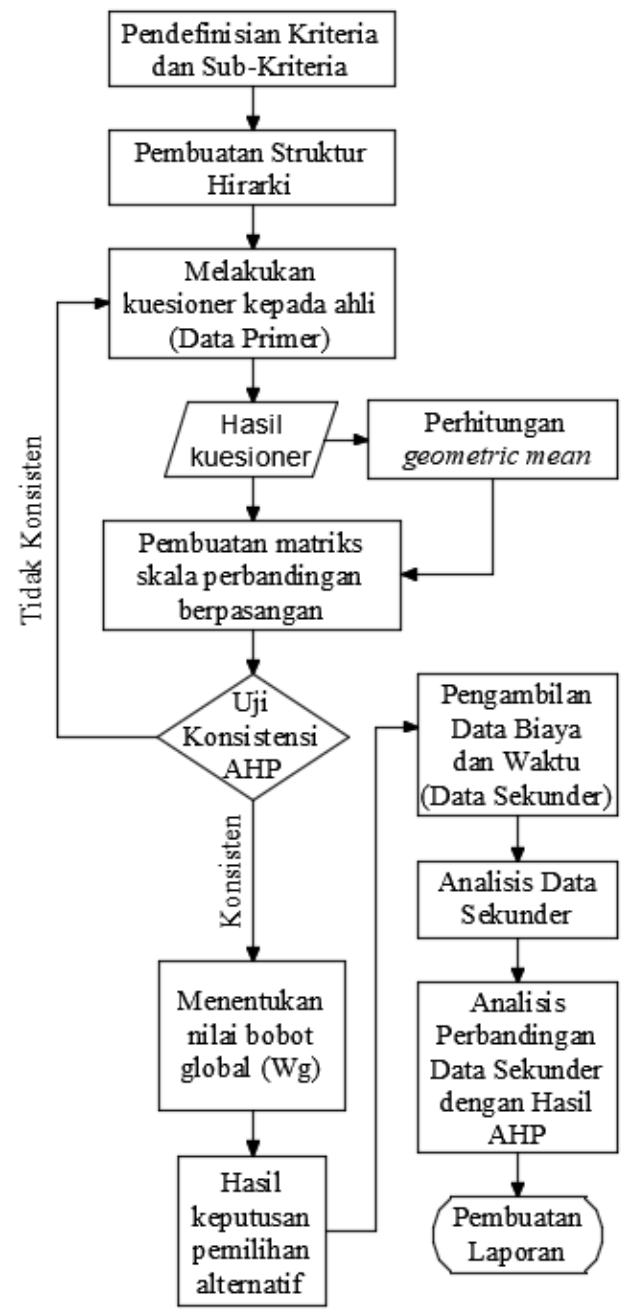

Gambar 1. Alur Kerja Kegiatan

Penelitian ini juga menganalisis hasil perbandingan biaya dan waktu penggunaan metode re-design BIM dan Konvensional di Proyek Jalan Tol Cibitung-Cilincing Seksi II serta menganalisis hasil dari kuisioner AHP dengan hasil.

\section{HASIL dan PEMBAHASAN}

Pada kuisioner AHP ada tiga kriteria utama, serta sembilan sub-kriteria serta tiga alternatif untuk pemilihan metode re-design yang didapatkan dari studi literatur, kemudian dibuat struktur hirarki seperti Gambar 2 pada lampiran. Struktur hirarki tersebut dibuat dari kriteria dan sub-kriteria yang terdapat pada Tabel 1, lalu disebar ke tujuh responden.
Tabel 1. Kriteria dan Sub Kriteria Analisis AHP

\begin{tabular}{|c|c|c|}
\hline No & Kriteria & Sub-Kriteria \\
\hline 1 & Biaya & Software \\
\hline 2 & Biaya & Hardware \\
\hline 3 & Biaya & Pelatihan SDM \\
\hline 4 & Waktu & $\begin{array}{c}\text { Waktu } \\
\text { Pelatihan SDM }\end{array}$ \\
\hline 5 & Waktu & $\begin{array}{l}\text { Waktu Re- } \\
\text { design }\end{array}$ \\
\hline 6 & Waktu & $\begin{array}{c}\text { Waktu } \\
\text { Pertukaran } \\
\text { Informasi }\end{array}$ \\
\hline 7 & Sistem & $\begin{array}{c}\text { Sistem } \\
\text { Organisasi } \\
\text { Dokumen }\end{array}$ \\
\hline 8 & Sistem & $\begin{array}{c}\text { Sistem } \\
\text { Pelatihan }\end{array}$ \\
\hline 9 & Sistem & $\begin{array}{c}\text { Sistem } \\
\text { Database }\end{array}$ \\
\hline
\end{tabular}

Hasil dari kuisioner oleh responden ahli berupa perbandingan berpasangan antar kriteria, sub-kriteria, dan alternatif dalam bentuk angka skala prioritas dari 1 sampai 9. Skala prioritas prioritas tersebut diolah menjadi matriks perbandingan berpasangan level kriteria (level 1) dari kuisioner dapat dilihat pada Tabel 2 berikut ini.

Tabel 2. Matriks Perbandingan Berpasangan Level Kriteria

\begin{tabular}{cccc}
\hline & Biaya & Waktu & Sistem \\
\hline Biaya & 1.00 & 0.33 & 5.00 \\
Waktu & 3.00 & 1.00 & 6.00 \\
Sistem & 0.20 & 0.17 & 1.00 \\
\hline
\end{tabular}

Hasil dari penilaian kuisioner yang diisi oleh responden, kemudian dicari satu nilai untuk satu matriks perbandingan berpasangan dengan menggunakan Geometric Mean seperti terlihat pada Tabel 3. 
Tabel 3. Hasil Geometric Mean Biaya terhada Waktu

\begin{tabular}{cc}
\hline Responden & $\begin{array}{c}\text { Hasil Kriteria } \\
\text { Biaya-Waktu }\end{array}$ \\
\hline 1 & 0.33 \\
2 & 8 \\
3 & 0.33 \\
4 & 7 \\
5 & 0.25 \\
6 & 1 \\
7 & 0.50 \\
Geometric Mean & 0.96 \\
\hline
\end{tabular}

Hasil penilaian ketujuh responden untuk perbandingan berpasangan Biaya-Waktu adalah : $\mathrm{R} 1=0.33, \mathrm{R} 2=8, \mathrm{R} 3=0.33$, $\mathrm{R} 4=7, \mathrm{R} 5=0.25, \mathrm{R} 6=0.05, \mathrm{R} 7=0.05$ dimana :

$$
\begin{aligned}
& \mathrm{R} 1=1 / 3=0.33 \\
& \mathrm{R} 3=1 / 3=0.33 \\
& \mathrm{R} 5=1 / 4=0.25 \\
& \mathrm{R} 7=1 / 2=0.50
\end{aligned}
$$

Dari ketuhuh data tersebut kemudian dicari rata-rata geometriknya yang terdapat pada Tabel 4 dengan perhitungan sebagai berikut :

$$
\begin{aligned}
& \text { Geometric Mean } \\
& =(0.33 \times 8 \times 0.33 \times 7 \times 0.2 \times 1 \\
& \quad \times 0.5)^{1 / 7} \\
& =0.96
\end{aligned}
$$

Tabel 4. Hasil Geometric Mean Antar Kriteria

\begin{tabular}{cccc}
\hline & Biaya & Waktu & Sistem \\
\hline Biaya & 1.00 & 0.96 & 1.89 \\
Waktu & 1.04 & 1.00 & 1.43 \\
Sistem & 0.53 & 0.70 & 1.00 \\
\hline
\end{tabular}

Selanjutnya, melakukan perhitungan Gometric Mean terhadap pasangan lain. Setelah mendapatkan perataan jawaban dengan Geometric Mean Theory selanjutnya dilakukan penjumlahan pada setiap kolom seperti pada Tabel 5 yang digunakan untuk pengujian berikutnya yaitu konsistensi matriks.

Tabel 5. Penjumlahan Tiap Kolom Pada Perbandingan Berpasangan Kriteria

\begin{tabular}{cccc} 
& Biaya & Waktu & Sistem \\
\hline Biaya & 1.00 & 0.96 & 1.89 \\
Waktu & 1.04 & 1.00 & 1.43 \\
Sistem & 0.53 & 0.70 & 1.00 \\
Jumlah & 2.56 & 2.67 & 4.32 \\
\hline
\end{tabular}

Selanjutnya, dilakukan normalisasi matriks dengan cara membagi angka di dalam setiap sel dengan jumlah angka pada kolom yang bersangkutan seperti contoh berikut :

Perbandingan Biaya terhadap Waktu = 0.96

Penjumlahan Kolom Waktu $=0.96+$ $1.00+0.70=2.67$

Normalisasi Biaya terhadap Waktu = $0.96 / 2.67=0.36$

Dari matriks yang telah dinormalkan dapat dihitung bobot prioritas $(W)$ dari masing masing kriteria dengan cara membagi hasil penjumlahan bobot pada

\begin{tabular}{|c|c|c|c|c|}
\hline 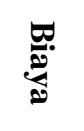 & 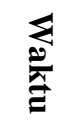 & $\frac{\omega}{\frac{\omega}{0}}$ & 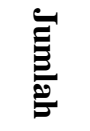 & $\sum$ \\
\hline 0.39 & 0.36 & 0.44 & 1.19 & 0.40 \\
\hline 0.40 & 0.38 & 0.33 & 1.11 & 0.37 \\
\hline 0.21 & 0.26 & 0.23 & 0.70 & 0.23 \\
\hline 1.00 & 1.00 & 1.00 & 1.00 & 3.00 \\
\hline
\end{tabular}
salah satu alternative (jumlah angka pada baris horizontal) dengan jumlah dari elemen yang dibobotkan $(N)$, yaitu 3 terlihat pada Tabel 6 .

Tabel 6. Normalisasi Bobot Penilaian Perbandingan Berpasangan Antar Kriteria

Contoh perhitungan untuk mendapatkan nilai $\mathrm{W}$ adalah sebagai berikut : 
Jumlah horizontal biaya $=1.19$

Jumlah elemen yang dibobotkan $(\mathrm{N})=3$

Bobot Prioritas $(\mathrm{W})=1.19 / 3$

$$
=0.40
$$

Setelah mendapatkan $\mathrm{W}$ yang dapat di lihat pada Tabel 5.17 maka dilanjutkan dengan perhitungan Consistency Ratio (CR). Apabila Consistency Ratio (CR) $\leq 10 \%$ maka matriks telah memenuhi syarat konsistensi [10].

Langkah pertama untuk melakukan uji konsistensi adalah dengan mengalikan nilai pada matriks dengan nilai Vektor Prioritas (W) yang telah didapat pada Tabel 6 sesuai dengan perkalian matriks untuk mendapatkan nilai BW.

Hasil Perhitungan ini dapat dilihat seperti berikut :

Matriks
$\left|\begin{array}{ccc}1.00 & 0.96 & 1.89 \\ 1.04 & 1.00 & 1.43 \\ 0.53 & 0.70 & 1.00\end{array}\right| \times\left|\begin{array}{c}0.40 \\ 0.37 \\ 0.23\end{array}\right|=\left|\begin{array}{c}1.20 \\ 1.11 \\ 0.70\end{array}\right|$

Dari hasil perhitungan, masing-masing baris pada $\mathrm{BW}$ dibagi dengan nilai $\mathrm{W}$ untuk menentukan harga $\lambda$, pembagian tersebut adalah seperti pada Tabel 7 berikut :

Tabel 7. Perhitungan Matriks untuk Memperoleh Nilai BW

\begin{tabular}{ccc}
\hline $\begin{array}{c}\text { Priority } \\
\text { Vector }(\boldsymbol{W})\end{array}$ & BW & $\boldsymbol{\lambda}$ \\
\hline 0.40 & 1.20 & 3.01 \\
0.37 & 1.11 & 3.01 \\
0.23 & 0.70 & 3.01 \\
\hline
\end{tabular}

Kemudian menghitung nilai rata-rata dari hasil perhitungan diatas dengan cara sebagai berikut :

$$
\begin{aligned}
& \lambda \max \\
& =\frac{\text { Pemjumlahan } \lambda \text { dari matriks }}{N} \\
& \lambda \max =\frac{3.01+3.01+3.01}{3}
\end{aligned}
$$

$$
\lambda \max =3.01
$$

Dengan nilai konversi, nilai diatas tersebut sebagai nilai $\lambda \max$ dan Consistency Index (CI) dihitung dengan mengikuti rumus berikut ini :

$$
\begin{aligned}
\mathrm{CI} & =\frac{\lambda_{\max }-n}{n-1} \\
& =\frac{3.01-3}{3-1} \\
& =0,01
\end{aligned}
$$

Untuk mendapatkan nilai Consistency Ratio (CR), dilakukan pembagian Consistency Index (CI) dengan Random Index (RI), untuk matriks 3 x 3 RI yang digunakan adalah 0.52 seperti yang ada pada Tabel 8 berikut ini :

Tabel 8. Nilai Random Index

\begin{tabular}{cc}
\hline Orde Matriks & Random Index \\
\hline 1 & 0,00 \\
2 & 0,00 \\
3 & 0,52 \\
4 & 0,89 \\
5 & 1,11 \\
6 & 1,25 \\
7 & 1,35 \\
8 & 1,40 \\
9 & 1,45 \\
10 & 1,49 \\
\hline
\end{tabular}

Nilai CR dapat di ditentukan dengan persamaan seperti berikut :

$$
\begin{aligned}
\mathrm{CR} & =\frac{\mathrm{CI}}{\mathrm{RI}} \\
& =\frac{0.01}{0.52} \\
\mathrm{CR} & =0,01
\end{aligned}
$$

Nilai konsistensi 0.01 atau sama dengan $1 \%$ dapat diterima karena lebih kecil dari $10 \%$ dan sesuai dengan syarat konsisten [10]. Langkah yang sama digunakan untuk menghitung CR pada kriteria dan sub kriteria. Hasil Perhitungan diperoleh pada Tabel 9 dan 10 sebagai berikut : 
Tabel 9. Perhitungan Consistency Index, Consistency Ratio dan Pembobotan dari setiap Kriteria

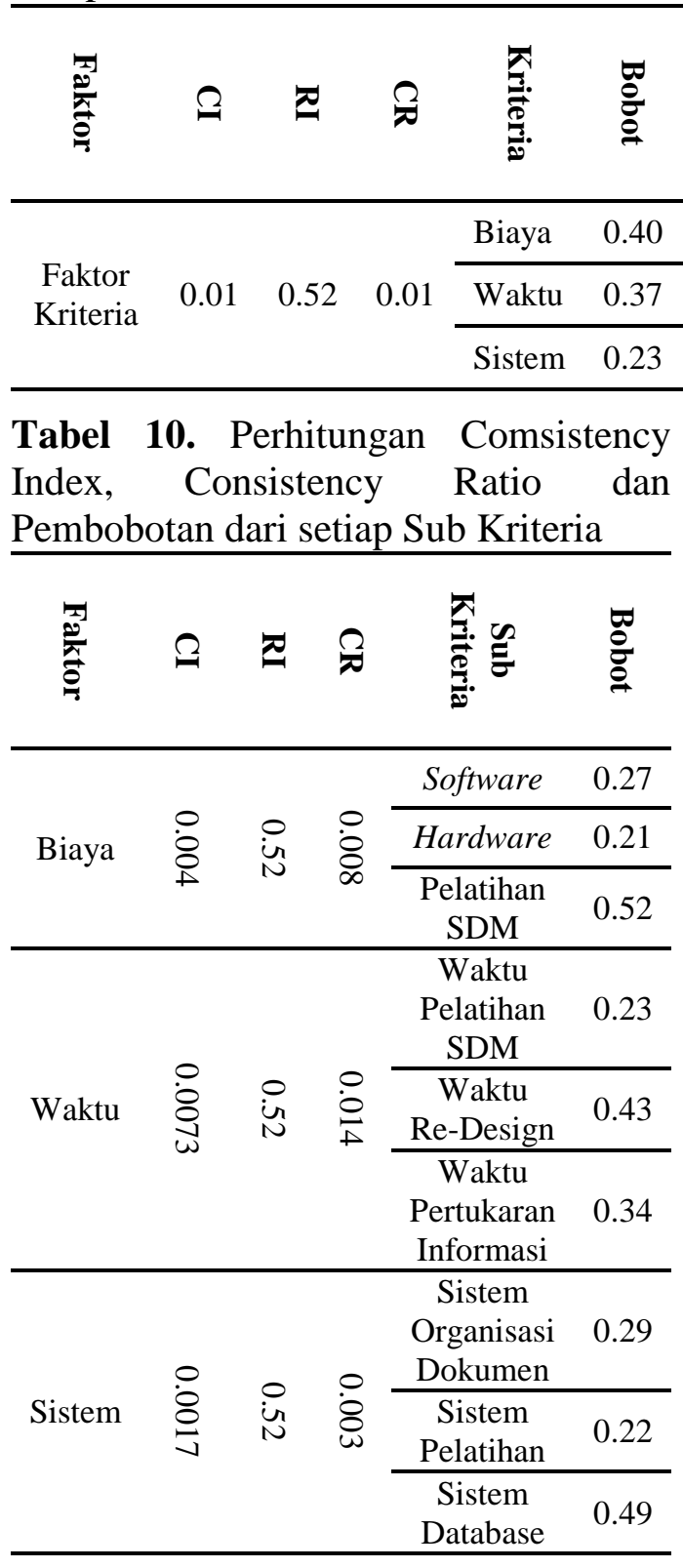

Dari data Tabel 9 dam 10 diatas dapat diketahui bahwa seluruh data memiliki nilai CR dibawah 0.10 atau $10 \%$. Sehingga dapat disimpulkan bahwa seluruh data telah konsisten dan dapat dianalisa lebih lanjut.

Setelah melakukan pengujian konsistensi matriks perbandingan maka pengujian yang dilakukan pada tahapan selanjutnya adalah pengujian konsistensi hirarki atau disebut dengan Consistency Ratio Hierarchy (CRH), menggunakan persamaan sebagai berikut:
$C R H=\frac{C I H}{R I H}$

Prinsipnya adalah dengan mengalikan semua nilai Consistency Index (CI) dengan bobot suatu kriteria yang menjadi acuan pada suatu matriks perbandingan berpasangan dan kemudian menjumlahkannya berikut nilai CIH terdapat pada Tabel 11 dan RIH yang terdapat pada Tabel 12 .

Tabel 11. Perhitungan Consistency Index of Hierarchy $(\mathrm{CIH})$

\begin{tabular}{|c|c|c|c|}
\hline & CI & $\begin{array}{l}\text { Bobot } \\
\text { Alternatif }\end{array}$ & CIH \\
\hline $\begin{array}{c}\text { Kriteria } \\
\text { Utama }\end{array}$ & 0.01 & 1.00 & $\begin{array}{c}0.00 \\
6\end{array}$ \\
\hline Biaya & 0.04 & 0.40 & $\begin{array}{c}0.00 \\
2\end{array}$ \\
\hline Waktu & 0.0073 & 0.37 & $\begin{array}{c}0.00 \\
3\end{array}$ \\
\hline \multirow[t]{2}{*}{ Sistem } & 0.0017 & 0.23 & $\begin{array}{c}0.00 \\
0\end{array}$ \\
\hline & Jumah & & $\begin{array}{c}0.01 \\
0\end{array}$ \\
\hline \multicolumn{4}{|c|}{$\begin{array}{l}\text { Tabel 12. Perhitungan Random Index of } \\
\text { Hierarchy (RIH) }\end{array}$} \\
\hline & RI & $\begin{array}{c}\text { Bobot } \\
\text { Alternatif }\end{array}$ & RIH \\
\hline $\begin{array}{l}\text { Kriteria } \\
\text { Utama }\end{array}$ & 0.52 & 1.00 & 0.52 \\
\hline Biaya & 0.52 & 0.40 & 0.21 \\
\hline Waktu & 0.52 & 0.37 & 0.19 \\
\hline \multirow[t]{2}{*}{ Sistem } & 0.52 & 0.23 & 0.12 \\
\hline & Jumah & & 1.04 \\
\hline
\end{tabular}

Langkah selanjutnya adalah membagi nilai dari total penjumlahan dari $\mathrm{CIH}$ dengan total penjumlahan RIH. Perhitungannya adalah sebagai berikut :

$$
\begin{aligned}
& C R H=\frac{C I H}{R I H} \\
& C R H=\frac{0.010}{1.04} \\
& C R H=0.01 \\
& C R H=0.01 \leq 10 \%=O K
\end{aligned}
$$


Nilai Consistency Ratio of Hierarchy (CRH) sebesar 0.01 lebih kecil dari 0.1 maka dapat dikatakan bahwa hirarki yang dibuat telah konsisten karena sesuai dengan syarat [10].

Tahap terakhir adalah menghitung bobot prioritas pemilihan alternatif, yang juga dihitung bobot lokal dan bobot globalnya, yang merupakan perkalian antara bobot lokal dengan bobot yang ada di level atasnya seperti pada Tabel 13 berikut ini :

Tabel 13. Hasil perhitungan bobot prioritas pemilihan alternatif

\begin{tabular}{|c|c|c|c|c|}
\hline \multirow{2}{*}{$\begin{array}{c}\text { Sub } \\
\text { Kriteria }\end{array}$} & \multirow{2}{*}{$\begin{array}{l}\text { Wg } \\
\text { Sub } \\
\text { Krit } \\
\text { eria }\end{array}$} & \multicolumn{3}{|c|}{ W Alternatif } \\
\hline & & $\begin{array}{c}\text { Konven } \\
\text { sional }\end{array}$ & $\begin{array}{c}\text { Semi } \\
\text { Konve } \\
\text { nsional }\end{array}$ & BIM \\
\hline Software & 0.11 & 0.12 & 0.26 & 0.62 \\
\hline Hardware & 0.08 & 0.09 & 0.25 & 0.66 \\
\hline $\begin{array}{l}\text { Pelatihan } \\
\text { SDM }\end{array}$ & 0.21 & 0.09 & 0.28 & 0.63 \\
\hline $\begin{array}{l}\text { Waktu } \\
\text { Pelatihan } \\
\text { SDM }\end{array}$ & 0.09 & 0.16 & 0.22 & 0.62 \\
\hline $\begin{array}{c}\text { Waktu } \\
\text { Re-Design }\end{array}$ & 0.16 & 0.09 & 0.22 & 0.69 \\
\hline $\begin{array}{c}\text { Waktu } \\
\text { Pertukaran } \\
\text { Informasi }\end{array}$ & 0.12 & 0.10 & 0.25 & 0.64 \\
\hline $\begin{array}{c}\text { Sistem } \\
\text { Organisasi } \\
\text { Dokumen }\end{array}$ & 0.07 & 0.07 & 0.25 & 0.68 \\
\hline $\begin{array}{l}\text { Sistem } \\
\text { Pelatihan }\end{array}$ & 0.05 & 0.09 & 0.23 & 0.67 \\
\hline $\begin{array}{c}\text { Sistem } \\
\text { Database }\end{array}$ & 0.11 & 0.07 & 0.21 & 0.71 \\
\hline
\end{tabular}

Untuk mendapatkan bobot alternatif, kalikan bobot global dengan nilai masing-masing alternatif, sehingga diperoleh pada Tabel 14 berikut:

Tabel 14. Bobot Global Alternatif

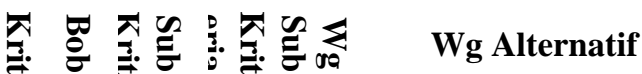

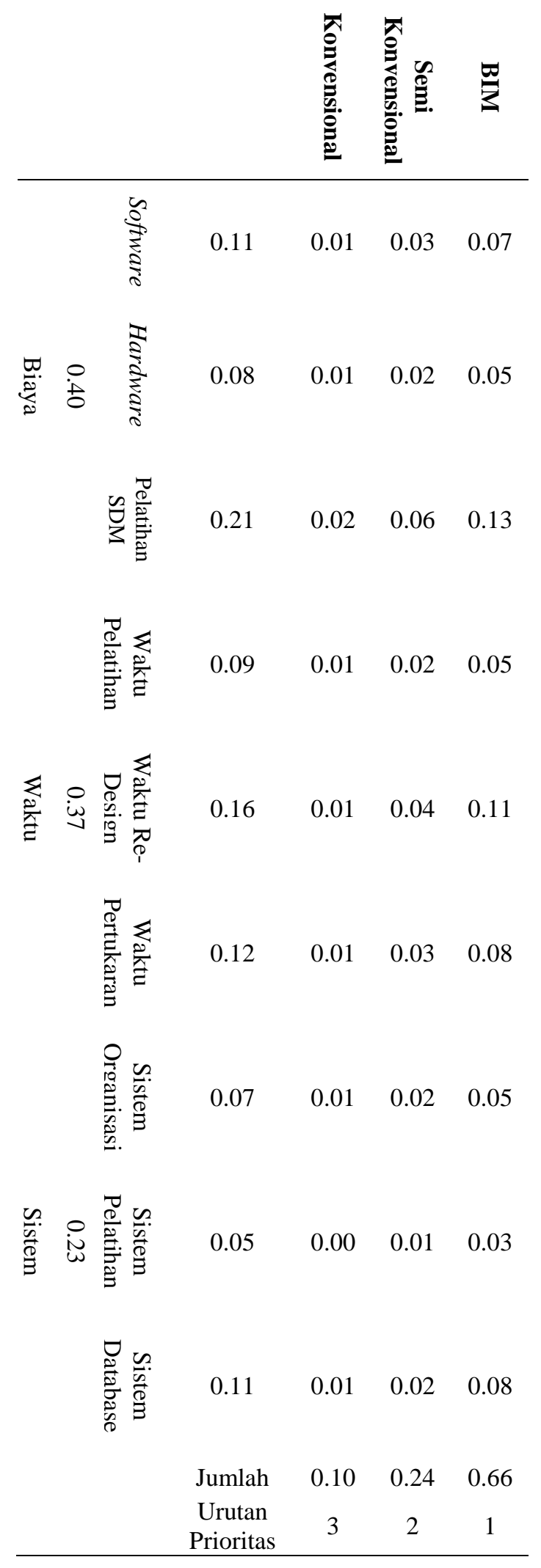

Secara global prioritas pemilihan metode perencanaan re-design adalah Metode Perencanaan BIM dengan bobot global 0.66 , kriteria yang menjadi prioritas adalah kriteria Biaya dengan bobot 
global 0.40, dan sub-kriteria yang menjadi prioritas adalah sub-kriteria Pelatihan SDM dengan bobot global 0.21 .

Hasil analisis biaya dan waktu di lapangan, Proyek Jalan Tol CibitungCilincing Seksi II, metode konvensional dilakukan oleh tim teknik site dan metode BIM dilakukan oleh tim BIM engineer kantor pusat. Data yang ada di lapangan ditunjukkan pada Tabel 15 untuk biaya konvensional, Tabel 16 untuk waktu konvensional, Tabel 17 biaya BIM, dan Table 18 untuk waktu BIM seperti berikut :

Tabel 15. Kalkulasi Biaya Metode Perencanaan Konvensional

\begin{tabular}{ccc}
\hline No & Uraian & Harga \\
\hline 1 & Biaya & Rp 38.600 .000 \\
& Software & \\
2 & Biaya & Rp 174.000.000 \\
& Hardware & \\
3 & Biaya & Rp 30.000 .000 \\
& SDMatihan & Rp 242.000.000 \\
\hline
\end{tabular}

Tabel 16. Kalkulasi Waktu Metode Perencanaan Konvensional

\begin{tabular}{ccc}
\hline No & Uraian & Waktu \\
\hline 1 & Waktu Pelatihan & 7 Hari \\
& SDM & \\
2 & Waktu Re-Design & 180 Hari \\
& & 187 Hari \\
\hline
\end{tabular}

Tabel 17. Kalkulasi Biaya Metode Perencanaan BIM

\begin{tabular}{ccc}
\hline No & Uraian & Harga \\
\hline 1 & Biaya & Rp 91.900 .000 \\
& Software & \\
& Biaya & Rp 360.000 .000 \\
& Hardware & \\
& Biaya & \\
3 & Pelatihan & Rp 80.000 .000 \\
& SDM & \\
\hline
\end{tabular}

\begin{tabular}{ll}
\hline Jumlah & Rp 531.900.000 \\
\hline
\end{tabular}

Tabel 18. Kalkulasi Waktu Metode Perencanaan BIM

\begin{tabular}{ccc}
\hline No & Uraian & Waktu \\
\hline 1 & Waktu Pelatihan & 14 Hari \\
& SDM & \\
2 & Waktu Re-Design & 60 Hari \\
& & 74 Hari \\
\hline
\end{tabular}

Dari analisis perbandingan antar kriteria diatas diperoleh untuk pekerjaan redesign dari segi biaya metode perencanaan BIM lebih mahal 54.5\% dari metode perencanaan konvensional, namun dari segi waktu metode perecanaan BIM lebih cepat menyelesaikan pekerjaan re-design hingga $60.4 \%$, dengan rincian biaya software metode perencanaan BIM lebih mahal $59 \%$ dari metode perencanaan konvensional, biaya hardware metode perencanaan BIM lebih mahal 51.6\%, serta biaya pelatihan SDM metode perencanaan BIM $62.5 \%$ lebih mahal dari metode perencanaan konvensional.

\section{KESIMPULAN}

Hasil yang diperoleh dari analisis AHP menyatakan Metode Perencanaan BIM sebagai alternatif yang dipilih ternyata lebih efektif daripada metode perencanaan konvensional, maupun semi-konvensional.

\section{DAFTAR PUSTAKA}

[1] T. M. Sudarsono, O. Christie dan Andi, "Analisis frekuensi, dampak, dan jenis keterlambatan 
pada proyek konstruksi," pp. 1-8, 2004.

[2] S. Winata dan Y. Hardalim, Faktor-Faktor Penyebab Rework pada Pekerjaan Konstruksi, Civil Engineering Dimension, 2009, pp. 22-29.

[3] A. Bradley, H. Li, R. Lark dan S. Dunn, "BIM for infrastructure: An overall review and constructor perspective," Automation in Construction, vol. 71, pp. 139152, 2016.

[4] Hatmoko, Jati Utomo; Dwi Fundra, Yulian; Wibowo, Mochamad Agung; Zhabrinna, "Investigating Building Information Modelling (BIM) Adoption in Indonesia Construction Industry," MATEC Web of Conferences, vol. 258, p. 02006, 2019.

[5] C. A. Berlian, R. P. Adhi, A. Hidayat dan H. Nugroho, "Perbandingan Efisiensi Waktu, Biaya, Dan Sumber Daya Manusia Antara Metode Building Information Modelling (BIM) dan Konvensional (Studi Kasus: Perencanaan Gedung 20 Lantai)," Jurnal Karya Teknik Sipil, p. 220 229, 2016.

[6] D. Smith, "Building Information Modeling (BIM) Approaches to Transforming the Construction Industry," AIA, p. 2, 2009.

[7] I. Ismael, "Keterlambatan Proyek Konstruksi Gedung Faktor Penyebab dan Tindakan Pencegahannya," Jurnal Momentum, pp. 46-56, 2013.

[8] S. Suciati, "Analisa Kelaikan Fungsi Jalan Berdasarkan Pendekatan Kuantitif Ahp," Teknik Sipil Siklus, vol. 3, pp. 3-4, 2017.

[9] E. Gonzalez, “An AHP-based Approach to Prioritizing," Center for Transportation Research, $\mathrm{p}$. 18, 2012.

[10] T. L. Saaty dan G. L. Vargas, Model, Methods, Concepts \& Application on The Analitic Hierarchy Process, Philadelphia: Springer, 2012. 


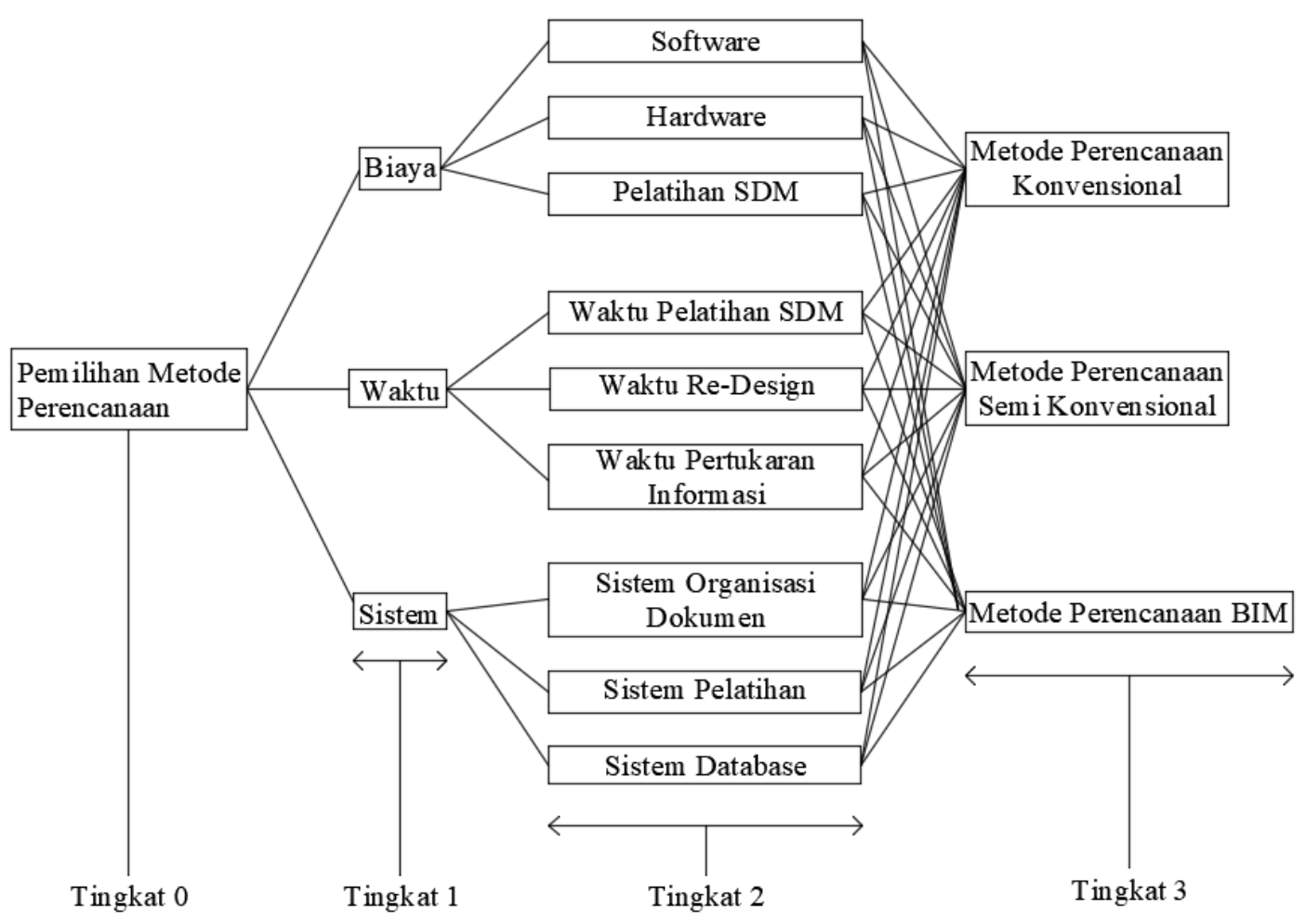

Gambar 2. Struktur Hirarki 